\title{
„Życie duchowe” a „życie w duchu” - dialogiczna dystynkcja Martina Bubera
}

\begin{abstract}
Abstrakt
Dla protagonisty współczesnej dialogiki, Martina Bubera, życie duchowe stanowi nie tyle ontyczny wyróżnik istnienia człowieka, ile szansę, przed którą człowiek stoi i którą powinien wykorzystać z uwagi na swoją dialogiczną genezę, która zarazem określa specyficzny horyzont jego egzystowania. Egzystowania niepodobna zredukować do istnienia obiektu pośród innych obiektów, gdyż może ono i powinno wyrażać się obecnością - byciem osoby wobec innych osób, byciem Ja wobec Ty. Podstawowa różnica między „życiem duchowym” a „życiem w duchu” polega na tym, że pierwsze, w odróżnieniu od drugiego, nie zawsze bywa dialogiczne oraz na tym, że nie zawsze uzyskuje ono wymiar etyczny i niejednokrotnie spełnia się w samym tylko wymiarze estetycznym. Tymczasem życie w duchu wskazuje na transcendentny status i proweniencję ducha, który nie może być postrzegany w kategoriach zjawiska będącego rezultatem kulturowego progresu - jako sublimacja lub jako projekcja tego, co immanentnie ludzkie.
\end{abstract}

Słowa kluczowe: Martin Buber, życie duchowe, życie w duchu, filozofia dialogu.

\section{Spiritual Life and Living in the Spirit - Martin Buber's Dialogical Distinction}

\begin{abstract}
For Martin Buber, the protagonist of the modern philosophy of dialogue, spiritual life is not an ontic distinction of human existence, but an opportunity that man has and should use because of his dialogical genesis, which determines the particular horizon of his being. Existing cannot be reduced merely to the existence of a given object among others, since it may and ought to be expressed via presence - being a person
\end{abstract}

\footnotetext{
* Uniwersytet Łódzki.

Artykuł otrzymano: 28.09.2020; akceptacja: 22.02.2021.
} 
to other people, being 'I' to 'You'. The fundamental difference between 'spiritual life' and 'living in the spirit' lies in the fact that the former, as opposed to the latter, does not always happen to be dialogical, that it does not always have an ethical dimension, and often fulfils itself in an aesthetic dimension only. On the other hand, living in the spirit indicates a transcendental status and the provenance of the spirit, which cannot be perceived as the result of cultural progress - it is regarded as the sublimation or projection of what is immanently human.

Keywords: Martin Buber, spiritual life, living in the spirit, philosophy of dialogue.

Wolno zaryzykować tezę, że specyficzny i wciąż niedoceniany nurt myśli współczesnej, określany mianem filozofii dialogu, najwięcej zawdzięcza Martinowi Buberowi. To właśnie ten autor nadał projektowi dialogicznemu wyrazistość, określił jego idiom, cele, wskazał jego zakorzenienie w filozoficznej tradycji, ale też uzasadnił jego aspiracje - zarówno krytyczne względem wcześniej wypracowanych filozoficznych koncepcji (zwłaszcza dotyczących filozofii człowieka), jak i zmierzające do otwarcia nowych horyzontów antropologiczno-filozoficznych. Buberowska dialogika oparta jest na dualnej wizji rzeczywistości - w tym rzeczywistości ludzkiej - a wtóruje jej inna dualność, nie jedyna, lecz szczególnie ważna, pozwalająca na odróżnienie dwu, pozornie tylko synonimicznych sposobów egzystencjalnego odnoszenia się człowieka do ducha. Założeniem tej dialogiki jest traktowanie ducha nie w kategoriach abstrakcyjnego pojęcia, którego treść i semantyczna wydolność byłaby tworem w pełni dostępnym filozoficznemu dyskursowi. Przeciwnie, Buber traktuje go jako niezależną od człowieka metafizyczną realność, a zarazem dostrzega w nim treść fundamentalnego doświadczenia określającego specyfikę ludzkiego życia. Celem niniejszego tekstu będzie zatem ocena koherentności i filozoficznej wiarygodności koncepcji Bubera dokonana przez pryzmat poczynionego przezeń rozróżnienia: „życie w duchu” vs. „życie duchowe”.

Podejmując problem duchowości, Buber stara się przybliżyć sens samego pojęcia. Czyni to zarówno w ramach pozytywnej charakterystyki ${ }^{1}$, jak i w sposób negatywny, odróżniając duchowość od wielorakich jej pozorów². Jednocześnie autor zakłada, że eksplikacji pojęcia duchowości niepodobna przeprowadzić metodą abstrahowania. Nie sposób uchwycić czynnika duchowego, ekstrahując go z ludzkiej egzystencji i rozpatrując w oderwaniu od całego kontekstu ludzkiego istnienia i funkcjonowania w świecie. Rzeczywistość ducha nie jest ludzką projek-

\footnotetext{
1 Max Scheler, dla którego duchowość człowieka jest darem, podkreślał niemożność kauzalnego ujęcia problematyki duchowości i stwierdzał, że w odniesieniu do tak „podstawowego warunku stania się człowiekiem”, jakim są intencjonalne akty duchowe - „wszelkie naturalistyczne «wyjaśnianie» zawodzi" (Scheler 1987: 37).

2 Np. John Hick, dostrzegając w człowieku „zwierzę religijne” oraz „istotę duchową”, upatruje w tym ów „piąty wymiar” określający i determinujący ludzką naturę. Nie wyjaśnia jednak jego proweniencji (Hick 2005: 35).
} 
cją, sublimacją lub efektem kulturowej transformacji, wszelako człowiek jest tym, kto go rozpoznaje, odnajdując w nim źródło wszelkiej duchowości (Buber 1992: 126). Człowieka określa nie tylko kontekst historyczno-kulturowy, niesprowadzalny jest również do kontekstu przyrodniczego. Określanie ludzkiego bytu w drodze konfrontowania go z innymi przedstawicielami świata animalnego byłoby niepełne i nieadekwatne ${ }^{3}$. Nie przyniosłoby spodziewanych rezultatów, gdyż prowadziłoby co najwyżej do ujawnienia „braków” człowieka na tle innych istot żywych4. Buber nie deprecjonuje perspektywy kulturowej i przyrodniczej, ale dostrzega w nich zaledwie materialne podłoże ludzkiej egzystencji pojmowanej jako relacyjna, interpersonalna obecność w świecie. Owo podłoże nie przesądza o wyjątkowości człowieka - nie jest ono „warunkiem dostatecznym”, lecz jest „warunkiem koniecznym” ludzkiego istnienia. Dopiero uwzględniając cały kontekst ludzkiego funkcjonowania w świecie, można, zdaniem Bubera, rozpoznać swoisty dla człowieka sposób egzystowania i w konsekwencji wyróżnić właściwą człowiekowi bezprecedensowość 5 .

\section{Dwie perspektywy}

Oba określenia, „życie w duchu” i „życie duchowe”, należąc do języka naturalnego, są umowne, toteż wymagają szerszej i w miarę precyzyjnej eksplikacji, będącej warunkiem właściwego odczytania ich sensów. Trzeba przyznać, że choć intencje Bubera budującego swą narrację na opozycji obu terminów są rozpoznawalne, to jednak autor nie zawsze wyraża się precyzyjnie, co niekiedy prowadzi do zamętu pojęciowego, którego uniknięcie wymaga uwzględnienia szerszego kontekstu wypowiedzi. „Życie w duchu” ma sens kontradykcyjny względem „życia duchowego". Buber nie pozostawia wątpliwości co do tego, że sens powyższych określeń jest różny, niesprowadzalny do jednego - któregoś z nich lub innego, mogącego być odpowiednikiem ich obu. Buber nie tylko odróżnia je od siebie, ale przeciwstawia je sobie: „To, co określa się mianem życia duchowego, jest zrazu przeszkodą dla życia człowieka w duchu" (Wehr 2007: 139). Taka deklaracja nie powinna dziwić nikogo, kto dysponuje choćby przeciętną orientacją w zakresie dwudziestowiecznej filozofii dialogu, a szczególnie jest czytelna w kontekście filozoficznego projektu Bubera, będącego jednym z najbardziej znanych i najwyrazistszych przedstawicieli tego

\footnotetext{
3 Takie założenie jest charakterystyczne również dla innych myślicieli spod znaku filozofii dialogu. Np. Abraham J. Heschel, który dodaje: „Gdy pytamy o człowieka, problemem nie jest jego nie podważalna zwierzęcość, lecz zagadka, co właściwie on robi z powodu i pomimo swojej zwierzęcości" (Heschel 2014: 53).

4 Taką drogą podążał ważny nurt filozofii człowieka, mający swe źródła w myśli starożytnej, a współcześnie kulminujący np. antropologiczno-filozoficznym projektem Arnolda Gehlena, z kluczową dlań kategorią człowieka jako istoty obarczonej niedostatkiem (Mängelwesen).

5 Składa się na nią zarówno „nierozkładalna, nieporównywalna, nieredukowalna” konkretność świata, jak i naznaczanie odpowiedzialnością za wszystko, co w każdej chwili, jedynej i nieporównywalnej z żadną inną, zwraca się ku człowiekowi (Buber 1992: 219; Buber 1973: 156-157).
} 
nurtu. Antropologiczno-krytyczny projekt Bubera zbudowany jest, jak wiadomo, na rozróżnieniu między dwiema ludzkimi „postawami” (Ja-Ty i Ja-To/Ono), któremu w warstwie językowej odpowiada rozróżnienie między dwoma „fundamentalnymi słowami" (Ja-Ty i Ja-To/Ono) ${ }^{6}$. Powyższa dystynkcja jest niewątpliwie konsekwencją przyjętego przez Bubera metafizycznego założenia, zakładającego realność transcendencji, której ranga i rola w filozoficznym dyskursie byłaby zbliżona do tej, jaką w tradycji filozoficznej pełni teistycznie rozumiane pojęcie Boga, choć dla Bubera, co często podkreśla, Bóg nie jest pojęciem ani ideą7

Niepodobna utożsamiać z sobą obu wymienionych typów manifestowania się ludzkiego życia, bowiem w każdej z nich słowo „duch” użyte jest w innym znaczeniu. Sformułowania: „życie w duchu” i „życie duchowe” wskazują na całkiem inną jakość ludzkiego życia - pierwsze, inaczej niż drugie, angażuje człowieka w całym spektrum jego egzystencji. Różnica między tymi określeniami jest więc fundamentalna i ściśle koresponduje z różnicą między myśleniem dialogicznym i monologicznym. Myślenie dialogiczne określa siebie jako myślenie z gruntu odmienne od tego, które patronowało niemal całej filozoficznej tradycji. Antropologicznym punktem wyjścia ma być nie immanentne Ja, lecz transcendentne Ty. Myślenie dialogiczne - jak pamiętamy - odwołuje się do Ty jako realności transcendentnej, źródłowej, nieredukowalnej do przedmiotu, niesprowadzalnej do To. Myślenie monologiczne, przeciwnie, domagało się i nadal domaga wyrażenia realności Ty w języku To. Jednak ten postulat już w swoim założeniu przekreśla możliwość uwzględnienia perspektywy dialogicznej, zgodnie z którą to właśnie Ty jest źródłem samowiedzy Ja. W tej perspektywie Ja, traktowane jako podmiot poznania czy doświadczania, musi być wtórne względem Ty, będącego dialogicznym partnerem inicjującym relację interpersonalną. W dialogice, odwrotnie niż w optyce Kartezjańskiej, idealistycznej, fenomenologicznej czy „transcendentalnej”, ani przedmiotowe, ani podmiotowe Ty nie jest alter ego. Przeciwnie, to Ja - będące osobą, ale też pewnym „przedmiotem” jako korelat poznania i aktywizujący się poznawczo podmiot - jest wtórne wobec Ty i stanowi niejako alter Ty. Ja jest bowiem „zagadnięte” przez Ty, i dopiero pod tym warunkiem staje się zdolne do rozpoznawania obu „przedstawień" świata - dialogicznego i monologicznego - oraz do wchodzenia w relacje dialogiczne lub do podejmowania aktywności poznawczych przebiegających w horyzoncie podmiotowo-przedmiotowym. Relacja dialogiczna, jak podkreśla Buber

${ }^{6}$ Celowo różnicuję pisownię - z myślnikiem lub z łącznikiem - przyjmowanych źródłowych postaw oraz fundamentalnych słów.

7 Buber podkreśla, że doświadczenie interpersonalnej obecności, czyli „bycia wobec drugiego”, obecności Boga - będącego „rzeczywistością, która przerasta ideę”, objawiającego swoją realność słowem Ehie, „oto jestem” - ma transcendentne źródło i podstawę, toteż nie jest możliwe sprowadzenie Boga do pojęcia (Buber 1994: 54). Zaskakująco zbieżne z tym będą stwierdzenia Lévinasa dotyczące niemożliwości ostatecznego ugruntowania kryteriów etycznych w immanentnej rzeczywistości ludzkich idei.

8 Takiego określenia używa Michael Theunissen, mając na myśli wieloraką i zróżnicowaną tradycję filozoficzną, opozycyjną względem dialogiki (por. Theunissen 1977: 244; por. Moser 1979: 89; por. Theunissen 1991: 256-279). 
wespół z innymi autorami, nie musi przebiegać w warunkach rozmowy i nie każda rozmowa wypełnia znamiona dialogu, w znaczeniu, które mamy tu na uwadze. Gdy jednak rozmowa uzyskuje status relacji dialogicznej, wówczas nie sposób kontrolować jej treści ani dynamiki, bowiem jej przebieg „należy do ducha i niejeden odkrywa to, co miał do powiedzenia, nie wcześniej, niż usłyszawszy wezwanie ducha" (Buber 1992: 153). Duchowość, wyrażająca się życiem w duchu, jest dla Bubera elementem decydującym o więzi człowieka z całą rzeczywistością, zwłaszcza z rzeczywistością transcendentną, Bogiem rozumianym jako źródło i ostateczna rękojmia ważności interpersonalnych relacji 9 .

Życie duchowe stanowi przeciwieństwo życia w duchu, ponieważ w sposób zawoalowany instrumentalizuje obszar będący potencjalną sferą dialogicznego partnerstwa. Jednym z przejawów życia duchowego jest dystansowanie się człowieka wobec świata, które polega na wypieraniu doświadczenia bezpośredniego przez doświadczenie pośrednie. Doświadczeniem bezpośrednim jest uczestnictwo w rzeczywistości, o którym Buber pisze w większości swoich tekstów, stanowiące jej uznawanie na poziomie egzystencjalnej interioryzacji (Innewerden). Jest ono odróżniane od obserwowania rzeczywistości (Beobachten), jej kontemplowania (Betrachten), poznawania lub przekształcania. Te ostatnie formy doświadczania odwołują się np. do form symbolicznych, które wprawdzie, jak podkreśla Paul Ricoeur, „dają do myślenia” (Ricoeur 1985: 58-75), lecz nie mogą zastąpić tej realności, która otwiera się wraz z wejściem $\mathrm{w}$ dialogiczne relacje uobecniające życie w duchu (Buber 1992: 215-216). Przykładem dystansowania się od życia w duchu jest specjalizacja, koncentrowanie się na poszczególnych formach aktywności, kanalizujących doświadczanie świata i partykularyzujących je stosownie do przyjętej wąskiej perspektywy poznawania lub użytkowania. Takie zjawisko i taki proces wykluczają jednak życie w duchu, gdyż utwierdzają monologiczne Ja w przeświadczeniu o przysługującej mu autonomii oraz o prawie do swobodnego użytkowania świata, do przekształcania go i manipulowania nim, zgodnie z własnymi oczekiwaniami i celami ${ }^{10}$. Wybierając życie duchowe, człowiek rezygnuje z dialogicznego partnerstwa właściwego życiu w duchu, gdyż to, co duchowe zostaje zinstrumentalizowane lub wchłonięte przez angażującą emocje sferę ludyczną. Trzeba ponownie podkreślić, iż Buberowska rekomendacja życia w duchu nie deprecjonuje innych form ludzkiego zaangażowania i ludzkiej aktywności, a jedynie wskazuje ich hierarchiczny porządek i akcentuje niepomijalność transcendentnego źródła, które nadaje ludzkiemu istnieniu wyjątkowy status.

\footnotetext{
${ }^{9}$ Zauważmy, że to założenie jest odmienne od przyjętego np. przez Schelera, dla którego zasada duchowa nie tylko przesądza o odmienności człowieka w stosunku do innych istot, ale ponadto „stoi poza tym wszystkim, co możemy nazwać «życiem» w najszerszym znaczeniu” (Scheler 1987: 81).

${ }^{10} \mathrm{~W}$ tym przypadku „doskonalenie ma się na myśli, kiedy mówi się o postępującym rozwoju życia duchowego. Oczywiście winnym się jest wtedy prawdziwego grzechu językowego przeciwko Duchowi; owo «życie duchowe» jest bowiem zazwyczaj przeszkodą dla życia człowieka w duchu" (Buber 1992: 62).
} 
Duchowi, podobnie jak słowu, przysługuje realność. Duch odsyła do źródeł rzeczywistości. Z kolei słowo, którym duch zwraca się do człowieka, jest czymś więcej niż elementarne medium sensu. W ten sposób życie w duchu i życie w słowie - zakładają siebie i dopełniają się. Duch, podobnie jak słowo - rzeczywiste, a nie sprowadzone do nośnika sensu czy pełniące zaledwie rolę medium porozumienia - cyrkuluje pomiędzy Ja i Ty. Poprzez relacje z innymi ujawnia się rzeczywiste i najpełniejsze istnienie człowieka:

Duch nie jest w Ja, lecz między Ja i Ty. Nie przypomina krwi, która w tobie krąży, lecz powietrze, którym oddychasz. Człowiek żyje w duchu, jeśli jest w stanie odpowiedzieć swojemu Ty. A jest w stanie, gdy całą swoją istotą wejdzie w relację. Tylko dzięki swej sile relacyjnej może człowiek żyć w duchu (Buber 1992: 62).

Podstawowym wyznacznikiem życia w duchu jest jego dialogiczny charakter. Przy czym chodzi tu nie tyle o binarność będącą formalnym warunkiem dialogu, ile o niesymetryczność dialogu. Ważne jest uznanie, że dialogiczna inicjatywa należy do transcendentnego Ty, które nigdy nie może ulec redukcji do alter ego. Powodem angażowania się w życie w duchu, podobnie jak powodem podejmowania dialogu, nie jest Ja, lecz Ty. Życie w duchu nie powinno być sprowadzane do ćwiczeń, dzięki którym Ja pracuje na rzecz swojej „duchowej kondycji” i duchowych kwalifikacji. Jest ono raczej próbą spłacenia długu zaciągniętego przez Ja w momencie, gdy stało się ono świadome swojego osobowego statusu.

Wyrazem życia w duchu jest gotowość do mówienia Ty. Istotne jest, by człowiek nie ograniczał swego życia do zobiektywizowanych form świata-To, by podejmował wysiłki pozwalające uobecnić się temu, co transcendentne względem wszelkiego poznawania, przeżywania i doświadczania. Przestrzenią, w której może się to dokonywać, jest każda ze sfer ludzkiego życia. Pierwszą jest sfera życia z przyrodą: „Tutaj relacja powstaje w mroku, nie osiągając progu języka” (Buber 1992: 41). Druga dotyczy przestrzeni międzyludzkiej: „Tutaj relacja jest jawna i ma kształt słowny. Możemy dawać i przyjmować Ty”. Trzecią jest sfera relacji z „istnościami duchowymi”. I chociaż tu relacja pozostaje skryta, pozajęzykowa, to jednak okazuje się językowo twórcza, odsłania bowiem dialogiczną źródłowość: „Nie słyszymy żadnego Ty, lecz mimo to czujemy się zagadnięci i odpowiadamy - tworząc, myśląc, działając: wypowiadamy naszą istotą podstawowe słowo, mimo że ustami nie możemy powiedzieć Ty" (Buber 1992: 41; Buber 1973: 10). W każdej z tych sfer człowiek wchodzący w relację dotyka skraju Wiecznego Ty - żyje w jego aurze. Określenie Wieczne Ty dotyczy Boga, jednak Buber, uwzględniając rodzaj prowadzonego dyskursu - antropologicznego, a nie teologicznego bądź aspirującego do statusu filozofii religii - używa terminów, których sens jest dostosowany do filozoficznego kontekstu.

Życie w duchu daje szansę osobowego uczestnictwa w świecie. Ludzka zdolność do życia w duchu wyraża tym samym zdolność człowieka do bycia osobą. 
Takiego sposobu bycia Buber nie wyprowadza z trwałych własności, które (jak np. rozumność czy wolność) określałyby człowieka niezależnie od dokonywanych przezeń wyborów. Trwałość takiego sposobu istnienia jest raczej funkcją ludzkiej gotowości do życia w duchu. To ostatnie spełnia się, ilekroć człowiek, żyjąc w codzienności, rozpoznaje swoje Ty. Owo Ty otwiera przed nim przestrzeń dialogu - niecodzienną, bo pozakulturową i pozanaturalną, ale właśnie dlatego ludzką.

\section{Świat-Ty jako otwarcie na transcendentny dar ducha}

Charakteryzując relację dialogiczną, Buber wielokrotnie podkreśla, że nie należy ona do immanentnego, przyrodniczo-kulturowego świata-To. Nie jest ona bowiem kulturowym osiągnięciem człowieka, lecz pierwszym i fundamentalnym warunkiem uczłowieczenia11. Podobnie też, o ile duchowość można uznać za efekt sublimacji ludzkich popędów lub etap rozwoju ludzkiej podmiotowości, o tyle ducha, i odpowiednio „życia w duchu”, nie powinno się w taki sposób diagnozować.

Buber w wielu tekstach podkreśla wagę duchowej warstwy ludzkiego życia. Zakłada, że filozoficzne pytanie o człowieka może być trafnie postawione jedynie pod warunkiem uwzględnienia szczególnej optyki, zabezpieczającej przed redukcjonizmem, który grozi zamknięciem człowieka w horyzoncie biologiczno-kulturowej immanencji. Postulowana przez Bubera perspektywa sytuuje duchową warstwę człowieka w kontekście „daru ducha” (Gabe des Geistes). Ów dar - otrzymany, ale też zobowiązujący do dzielenia się nim - przysługuje jedynie człowiekowi, stanowi wyróżnik jego istnienia (Buber 1992: 146; por. Glinkowski 2011: 136). Nadmieńmy, że zjawisko ekspansji rzeczywistości uprzedmiotowionej, która dokonuje się za cenę marginalizacji sfery interpersonalnej, dostrzegli również autorzy dalecy od współczesnej myśli dialogicznej, czego dowodzi diagnoza: „Im bardziej indywiduum jest zainteresowane władzą nad rzeczami, tym bardziej rzeczy nad nim dominują, tym bardziej brakuje mu cech rzeczywiście indywidualnych, tym bardziej jego duch przekształca się w automat sformalizowanego rozumu" (Horkheimer 2007: 137). Powyższe zjawisko prowadzi do przejęcia życia społecznego przez podmioty użytkujące, co wiąże się z uszczuplaniem autonomii ludzkiej podmiotowości (por. Glinkowski 2011: 147). W obrębie świata-To nie ma miejsca na dar, gdyż całe uniwersum tego świata wyczerpują zjawiska, obiekty i procesy - dające się poznać, objaśnić w planie przyczynowo-skutkowym oraz pozostające we wzajemnych współzależnościach dynamicznych, organicznych i strukturalnych. Świat-To jest manifestacją immanencji, ponieważ koresponduje

\footnotetext{
11 „Dialog nie jest kwestią (Angelegenheit) duchowego luksusu i duchowego używania, jest rzeczą (Sache) stworzenia (Schőpfung), rzeczą stworzonego (Geschőpfs), a jest nim on, człowiek, o którym mówię, o którym mówimy - pospolita niezastąpioność (triviale Unersetzlichkeit)" (Buber 1992: 243; Buber 1973: 190-191).
} 
z pragmatycznym, instrumentalnym nastawieniem człowieka, który ma na celu eksploatowanie świata i, co z tym związane, uczynienie go przejrzystszym i przystępniejszym. Pojawia się tu prawidłowość: rozrastanie się zawłaszczonego przez człowieka obszaru świata, czyli świata-To, sprzyja jego poznawaniu, doświadczaniu, użytkowaniu. Wraz z nabywaniem coraz wyższych kwalifikacji (Erwerben von Kenntnissen) w zakresie rozporządzania światem-To, człowiek katalizuje kulturowy progres, dokonujący się $\mathrm{w}$ planie aktywności intelektualnej (np. zdolność do myślenia abstrakcyjnego), jak i utylitarno-praktycznej (np. opanowywanie wyspecjalizowanych umiejętności i zaawansowanych technologii) (por. tamże: 148).

Do powyższych kompetencji, zdobywanych w obrębie świata-To, można zaliczyć także zdolność do autodoskonalenia się człowieka w ramach rozmaitych praktyk medytacyjnych lub treningów dyscyplinujących i stymulujących sferę psychiczno-intelektualną, jednak nie koresponduje to z ludzką gotowością do angażowania się w „życie w duchu”. Ekspansja obszaru przedmiotowego i podążającej za nim dziedziny ludzkich umiejętności wyzwala u człowieka skłonność do marginalizowania potencjału relacyjnego (Beziehungskraft), który jako jedyny pozwala realizować życie w duchu (Buber 1992: 41, 45). Ten, kto rezygnuje z życia w duchu, przypisując temu, co duchowe funkcje instrumentalne lub sprowadzając go do sfery ludycznej, której źródłem nie jest transcendentny w swej proweniencji „dar ducha”, lecz immanentny i przejęty z tradycji rytuał (Whitehead 1997: 35), dokonuje polaryzacji polegającej na przeciwstawieniu instrumentalnie rozumianych: Ja i To, przy czym do sfery „To” zalicza innych ludzi. Ignorowanie różnicy między transcendencją ducha a immanencją duchowości prowadzi do redukcjonizmu (por. Barbour 1984: passim) oraz nadmiernie dowartościowuje perspektywę egotyczną, afirmującą indywidualizm, kosztem życia wspólnotowego, a jednocześnie sfera publiczna ulega instytucjonalizacji, która czyni ją anonimową (por. Glinkowski 2011: 148).

Tymczasem świat-Ty odsyła do transcendencji niepoznawalnej, niedającej się zawłaszczyć, uprzedmiotowić, użytkować, ale będącej źródłem i rękojmią zarówno osobowego statusu człowieka, jak i ludzkiego bycia obecnym w świecie. Buber zakłada, że tak jak „obecność” nie jest tożsama z ontycznym „bytowaniem/istnieniem”, tak również „świat” nie jest tożsamy ze „środowiskiem” (Umwelt), w jakim bytują istoty żywe, ani doń sprowadzalnym. 0 ile bowiem życie duchowe może stać się udziałem każdego, kto o nie zabiega i kto się na nie decyduje, a zatem leży ono w zasięgu podmiotu, o tyle źródłem i przestrzenią życia w duchu jest transcendencja. Takie życie jest pochodzącym od transcendencji „darem ducha”, jednak w odróżnieniu od innych darów nigdy nie staje się on wyłączną własnością beneficjenta, lecz pozostaje darem udzielonym warunkowo i tymczasowo ${ }^{12}$.

\footnotetext{
12 Jak pisze autor, „wzniosła nostalgia” (erhabene Schwermut) ludzkiego losu polega na tym, „że w naszym świecie każde Ty musi stać się To" (Buber 1992: 48, 53, 101).
} 


\section{Życie w duchu jako wydarzenie}

Uczestnictwo w życiu w duchu jest uczestnictwem w wydarzeniu. Duch wydarza się, jest darem, którego udzielanie i otrzymywanie zakłada obecność „woli i łaski”, czyli przebiega $\mathrm{w}$ warunkach bezinteresowności darczyńcy oraz wolności, czyli dobrowolnego otwarcia się na dar ze strony beneficjenta (Buber 1992: 42). Przyjęcie daru wymaga od ludzkiego Ja udzielenia odpowiedzi na zagadnięcie skierowane doń przez Ty. Bezpośredni, czyli niezapośredniczony pojęciami, lecz wymagający egzystencjalnego zaangażowania, dostęp do Ty - dialogiczna relacja z nim - wyklucza problematyzację podejmowaną na poziomie teoretyczno-poznawczym.

Pytań o ducha niepodobna zaaranżować, a odpowiedzi należy szukać nie tyle w tej przestrzeni, gdzie duch stał się „dziełem i zawodem”, lecz w obszarze, w którym trwa jako wydarzenie (Buber 1993: 80). Człowiek udziela odpowiedzi, wykorzystując różne języki: język mowy (Zungen der Sprache), język sztuki, język działania. Za każdym razem z tajemnicy wydarzenia wyłania się jeden duch będący słowem ${ }^{13}$. Poszczególne odpowiedzi, przybierające najrozmaitsze formy i będąc kanalizowane różnorodnymi dostępnymi człowiekowi technicznymi środkami wyrazu, są partykularnymi przejawami fundamentalnego procesu. Buber, nawiązując do Maxa Schelera, rozpoznaje ducha jako „pęd do słowa”, przy czym upatruje w tym dialogicznej i wspólnotowej natury człowieka (Buber 1993: 81).

Jednak odpowiadanie, będące ludzkim akcesem do relacji dialogicznej, stanowi zarazem zapowiedź jej unieważnienia. Im bardziej zdecydowanej odpowiedzi człowiek udziela swojemu Ty, tym silniejsza okazuje się pokusa jego uprzedmiotowienia. Jedynie milczenie, świadoma rezygnacja z użycia któregokolwiek spośród „języków mowy”, zdołałoby powstrzymać proces reifikacji, degradację Ty do To. Owo milczenie, poprzestające na przedjęzykowej, nietematyzującej obecności, uwalnia Ty i pozwala ocalić relację. W takiej sytuacji duch ujawnia się jedynie latentnie, jako obecny. Ta obecność, będąc obecnością Ty, zawiesza wszelkie wypowiedzi mające charakter orzekania.

Uprzedmiotawiające wypowiadanie się i orzekanie przebiega w warunkach korzystania z aparatu pojęciowego, a tym samym „wiąże Ty w świat To” (Buber 1973: 42). Nie wynika z tego jednak, by człowiek powinien lub musiał porzucać tematyzujący i problematyzujący sposób odpowiadania, co przecież warunkuje jego funkcjonowanie w obrębie rzeczywistości kulturowej. Człowiek nie powinien zrezygnować z orzekania, które warunkuje powstanie i progres nauki, sztuki, cywilizacji. Ważne jest, by nie ograniczał się do budowania i afirmowania świata-To i był gotów podejmować wysiłki na rzecz wchodzenia w relacje z tym, czego doświadcza w jego byciu uobecnionym (por. Glinkowski 2011: 149-150). Swej woli poznawania i rozporządzania człowiek nie powinien udzielać autonomii, gdyż nie

\footnotetext{
13 Buber pisze tu o „wielojęzyczności” człowieka w szerszym sensie niż ten, na który zwracają uwagę współcześni językoznawcy (por. Paepcke 1990).
} 
wyczerpuje ona osobowego charakteru ludzkiego istnienia, toteż za nadrzędną - zarówno w planie genetycznym jak i normatywnym - powinna być uznana wola relacji. Poruszanie się w świecie obiektów, w świecie-To - budowanie go, użytkowanie, poznawanie i modyfikowanie, przebiegające $w$ kategoriach utylitarno-technicznych i w perspektywie pragmatycznej racjonalności - jest nieuniknione, jednak nie powinno ono prowadzić do rezygnacji z uczestnictwa w świecie-Ty. Obserwowane współcześnie tryumfy techniki, gospodarki i polityki nie powinny być argumentem za marginalizacją relacji dialogicznej, za ignorowaniem dialogicznego wezwania płynącego od Ty, które „unosi się nad światem-To, jak duch nad wodami" (Buber 1992: 68). Konsekwencją takiej rezygnacji, redukującej i degradującej ludzką egzystencję do poziomu istnienia, rozpoznawanego $\mathrm{w}$ perspektywie pozadialogicznej i właściwego wszelkim przedmiotowo traktowanym bytom, byłoby wyzbywanie się autentycznego życia, pozbawienie go harmonii i celu, pogrążenie w ontycznej uniwersalności.

Szczególne miejsce przyznaje Buber dziedzinie sztuki i artefaktom tworzonym w ramach działalności artystycznej. Jest to sfera „istności duchowych” (geistigen Wesenheiten) (Buber 1992: 41, 103; Buber 1973: 10,103). Działalność artystyczna winna być traktowana jako świadectwo składane obecnemu w tej sferze duchowi i jako udzielana mu odpowiedź. Twórca dokonuje tego, ilekroć zawiesza własne słowo, a swój gest artystyczny czyni narzędziem działającym na rzecz ujawnienia się ducha. Istotą relacji między artystą a dziełem jest ujawnienie się ducha uobecniającego się w kształcie dzieła. Duch objawia się tu jako Ty, które „zagaduje go z ciemności, a on [artysta] odpowiada swoim życiem”. Duch okazuje się aktywnym partnerem, w tym przypadku poprzez dzieło, które: „nie stoi gotowe, [lecz] bezustannie nadchodzi ku niemu [ku artyście] i go dotyka" (tamże: 64; tamże: 44).

Ukierunkowanie na potrzeby nie może i nie powinno wypierać pragnienia współobecności. Bycie obecnym, uwiarygodniające ludzki sposób istnienia, staje się dostępne człowiekowi w kontekście dialogicznej współobecności. Ma to miejsce wtedy, gdy uznaje on siebie za obecnego dzięki i poprzez rozpoznanie duchowej istoty. Jest to ta sama istota, za sprawą której uzyskuje on dostęp do egzystencjalnego doświadczenia obecności, czyli istnienia w obliczu dialogicznego Naprzeciw. Tym różni się uniwersum świata człowieka od partykularnych środowisk innych żywych istot, że dochodzi w nim do relacji między człowiekiem i jego dialogicznym partnerem ${ }^{14}$. Dawanie świadectwa swemu byciu obecnym, czyli takiemu egzystowaniu, które jest warunkiem życia w duchu, i wymagające zarazem pełnego zaangażowania, dokonuje się wówczas, gdy człowiek całą swą istotą i całym życiem odpowiada na dialogiczne zagadnięcie. Owo pełne zaangażowanie się człowieka,

\footnotetext{
${ }^{14}$ Różnica między statusem świata-Ty i statusem świata-Naprzeciw nie jest tu istotna, toteż nie będzie szczegółowo omawiana. Poprzestańmy na stwierdzeniu, że ów świat-Naprzeciw jawi się wówczas „kiedy konkretny byt zostaje skonfrontowany ze spoistą całością bycia jako czymś samodzielnym” (Anzenbacher 1992: 170); inaczej mówiąc wówczas, „gdy kontekst bytu staje samodzielnie naprzeciw bytu, gdy staje się samodzielnym Naprzeciw" (Buber 1992: 128).
} 
wchodzenie $\mathrm{w}$ relację dialogiczną, jest warunkiem ujawnienia pełnego sensu rzeczywistości ${ }^{15}$. Ta sytuacja, bycia zagadniętym przez Ty i pozostawania w jego obliczu, nie jest ani jednorazowa, ani finitystyczna, nie poddaje się też petryfikacji, gdyż jest procesem, w którym jesteśmy „zagadywani przez znaki przytrafiającego się życia" (Buber 1993: 221; Buber 1973: 159) ${ }^{16}$.

Co ciekawe, Buber nie dąży do zamknięcia relacji dialogicznej w jednej formie, uznawanej za kanoniczną i dającej się rozpoznać jako określonego rodzaju zjawisko. Postać, jaką relacja przybiera, jest drugorzędna względem tego, co przesądza o zaistnieniu i trwaniu w stanie relacji. A zatem wszelka jej egzemplifikacja (może nią być nie tylko fenomenalnie rozpoznawany dialog, ale np. praca ${ }^{17}$ ) jest tylko czymś akcydentalnym i drugorzędnym względem rzeczywistości dialogicznego Pomiędzy, które jest jej swoistym obszarem oraz jej bezprecedensową jakością. Relacja nie wymaga urzeczywistnienia w konkretnych bytowo-kulturowych realiach. Obszaru, w którym się spełnia, nie sposób utrwalić czy zachować. Toteż relacja nigdy nie osiąga absolutnej trwałości i wymaga nieustannego ponawiania, ciągłego pytania o jej granice, jak również wytrwałego poświadczania jej rangi, jaką posiada dla ludzkiej egzystencji.

Świadomy zagrożeń wynikających z marginalizowania dialogicznego wymiaru ludzkiego istnienia, Buber postuluje poddanie owego istnienia rygorom ducha. Zarówno w sferze prywatnej, jak i publicznej dialogiczne relacje pozostają rzeczywiste dopóty, dopóki zachowana zostanie autonomia ducha jako dialogicznego, interpersonalnego rdzenia ludzkiego bycia osobą. Życie w duchu, przebiegające zarówno w wymiarze kameralnym, w przestrzeni prywatnej, jak i w skali organizmu społecznego, odznacza się integralnością - zarówno wewnętrzną, jak i zewnętrzną. Wewnętrzna zaświadcza o tym, że nie jest ono jednym z odosobnionych rewirów, lecz partycypuje ono w życiu społecznej całości. Integralność zewnętrzna przekonuje, iż życie podlega oddziaływaniu niewyizolowanego ducha „w sobie”, lecz ducha będącego „w świecie”. Wyrazem życia w duchu jest zdolność mówienia Ty, dokonującego się w każdej sferze relacji (w relacjach z innymi ludźmi, z przyrodą oraz z „istnościami duchowymi”), a także na każdym poziomie - zarówno w mikroskali na poziomie rodziny, jak też w makroskali zjawisk społecznych. Fundamentem takiego życia pozostaje wydarzenie spotkania - dialog, w którym Ja wchodzi w relację z Ty. Udzielając odpowiedzi swojemu Ty, Ja podejmuje „istotowy akt ducha" (Buber 1992: 72), przy czym angażuje się w ów akt całym swoim osobowym istnieniem. Budowana w ten sposób wspólnota pozostaje tak długo żywa, jak długo żywa i twórcza będzie zdolność do wchodzenia w dialogiczną relację i do

\footnotetext{
${ }^{15}$ Autor stwierdza: „Sens zostaje znaleziony wtedy, gdy dla jego wyjawienia człowiek zaangażuje całą swą osobę" (Buber 1994: 32).

${ }^{16}$ Tę sytuację trafnie oddaje współczesny badacz: „Wydarzenie, obecność (Vorkommen) i spotkanie istnieją jedynie o tyle, o ile jest się w drodze” (Böckenhoff 1970: 437-438).

${ }^{17}$ Pełna afirmacja pracy może dokonać się, wedle Bubera, jedynie poprzez duchowe zaangażowanie znamienne dla relacji Ja-Ty. Dopiero ona pracę czyni źródłem radości, a własności przywraca rangę tego, co zasłużenie nabyte (Buber 1992: 69; Buber 1973: 52).
} 
jej podtrzymywania. Owe relacje, jak pamiętamy, mają swe źródło nie w immanentnej sferze kulturowych artefaktów, lecz w transcendentnej rzeczywistości ducha, szerszej i bogatszej aniżeli ontyczne uniwersum, które człowiek rozpoznaje jako świat obiektów. Każda kultura, która marginalizując rzeczywistość dialogicznych relacji, nie pozostawia miejsca dla ducha, wpisuje go w immanencję własnej skończoności i historyczności, skazana jest nie tylko na skostnienie, ale też degraduje człowieka, zamyka go w świecie-To, w którym duch musi być uznany za iluzję lub projekcję.

Obserwowane przez Bubera i symptomatyczne dla współczesności zjawisko wyrzekania się ducha niesie destruktywne konsekwencje dla ludzkiego życia - rezygnacja z pierwszego implikuje postawę rezygnacji względem drugiego (Buber 1973: 51). Jednak szkody wynikające z duchowej autoalienacji są dostrzegalne dopiero w dłuższym horyzoncie czasu. Manifestują się one nie tylko narastającą instytucjonalizacją życia społecznego, ale też atomizacją jego uczestników, którzy stopniowo degradowani są do roli biernych obserwatorów - pozbawionych „żywej relacji względem ośrodka" (lebendige Beziehung zur Mitte), a zarazem przyzwalających na trwanie owego procesu. Buber dostrzega jednak szansę na zachowanie łączności między podmiotami rzeczywistości społecznej a duchową podstawą ich życia - osiągalnej zarówno w skali jednostkowej, jak i społecznej. Zarówno bowiem afirmacja dokonujących się relacji dialogicznych, jak też uświadamianie sobie granicy, która oddziela je od stosunku uprzedmiotawiania, daje nadzieję na podtrzymanie gotowości do ich tworzenia i restytuowania. Niejednokrotnie przebiega to w sposób latentny, zdarza się bowiem, że nawet człowiek, który „czuje się niezdolny do czystego urzeczywistnienia Ty", działa na rzecz afirmacji relacji dialogicznej ze swoim Ty, gdy „codziennie według prawa i miary tego dnia, poświadcza je (...) na nowo wytyczając granicę - odkrywając granicę" (Buber 1992: 69). Pamiętajmy, że wedle Bubera jedynie w wymiarze duchowym, a zatem w sferze życia w duchu, można rozpoznać, czy obszar tego, co posiadane i użytkowane jest podniesiony do wymiaru ludzkiego Naprzeciw, czy przeciwnie, ulegnie degradacji do sfery To i w niej zamknięty. Stosownie do takiej diagnozy, za fundament, na którym powinny być oparte wszelkie projekty doskonalenia relacji społecznych, politycznych lub ekonomicznych, należy uznać ich duchowe źródło ${ }^{18}$. Instytucje państwa nigdy nie staną się sprawiedliwe i przyjazne względem osobowego statusu człowieka, któremu w założeniu winny służyć, jeśli ich tworzenie i funkcjonowanie nie będzie uwzględniało sfery ducha uzewnętrzniającej się relacjami tworzącymi międzyosobową wspólnotę. Życie wspólnotowe, kierując się duchem, nie może ulec żadnej z dwóch potencjalnie zagrażających mu deformacji - podporządkowaniu instytucjom państwa bądź rozczłonkowaniu na partykularne, odseparowane od siebie enklawy. Żywy, działający duch, warunkujący integrację wspólnoty, nigdy nie jest odseparowanym od świata duchem „samym w sobie”,

\footnotetext{
18 Tym samym, kwestionując założenie Marksa, stwierdzi: „(...) nie można wybawić pracy i posiadania wychodząc od nich samych, a tylko wychodząc od ducha" (Buber 1992: 69).
} 
gdyż trwa jako „duch w świecie”. Zarazem jednak, mając swe źródło w transcendencji, wychodzi naprzeciw otwartemu nań światu. Dopełnieniem charakterystyki ducha, umożliwiającym rozpoznawanie go jako zarówno trwającego w świecie, jak i wychodzącego ku światu, jest udzielona człowiekowi zdolność mówienia Ty.

\section{Dwa oblicza samotności}

Skoro Heschel pisał: „Religia nie jest tym, «co człowiek robi ze swą samotnością». Religia jest tym, co człowiek robi z obecnością Boga" (Heschel 2001: 55; por. Heschel 2008: 9), to wypowiedź ta dobitnie ilustruje różnicę między tym co immanentne, a tym co transcendentne. Podążający tym samym tropem Buber wprowadza ważne rozróżnienie, gdy analizuje zjawisko samotności. Czymś innym jest bowiem samotność będąca konsekwencją porzucenia istot przez człowieka, a czymś innym samotność niezawiniona, gdy „człowiek zostaje porzucony przez istoty, do których mówił Ty" - jedynie w tym przypadku człowiek jest usprawiedliwiony i „zostanie przyjęty przez Boga” (Buber 1992: 104). Jeszcze innym kryterium Buberowskiego rozróżniania między rodzajami samotności jest to, czy stanowi ona cel, czy też środek prowadzący do celu.

Trudność w rozpoznawaniu sensu kryjącego się w kategorii ducha wynika w dużym stopniu z nawyków utrwalonych w filozoficznej tradycji, która podmiotu budującego dyskurs upatrywała zazwyczaj w pojedynczym Ja - niezależnie od tego, czy było to Ja idealizmu, transcendentalizmu czy fenomenologii. Ta trudność ujawnia się również w kontekście recepcji Buberowskiej dialogiki, choćby w tej krytycznej uwadze: „Można by wątpić, czy jest to prawdziwa dychotomia: Duch wrodzony Ja, czy duch wrodzony stosunkowi Ja-Ty" (Rotenstreich 1963: 112). Autor tych słów nie uwzględnia jednak okoliczności, że Ja, zgodnie z koncepcją Bubera, nigdy nie jest indyferentne wobec relacji dialogicznej. A zatem Ja albo identyfikuje się z nią jako korespondujące z fundamentalnym słowem Ja-Ty, albo wycofuje się z niej jako przynależne uprzedmiotawiającej perspektywie Ja-To. Pisząc: „Duch nie jest w Ja, lecz między Ja i Ty”, Buber sygnalizuje zewnętrzność ducha względem Ja monologicznego, zdystansowanego od relacji. Potwierdza to choćby taka wypowiedź: „Człowiek żyje w duchu, gdy jest on w stanie odpowiedzieć swemu Ty" (Buber 1992: 62). Na krytyczną wątpliwość komentatora można by odpowiedzieć: duch jest wrodzony Ja dialogicznemu, a tym samym dialogicznej relacji, której Ja zawdzięcza możliwość swej samoidentyfikacji.

Niektóre z intuicji Bubera stanowią polemikę z mistycyzmem, a przynajmniej z pewnymi jego odmianami ${ }^{19}$. Jeśli bowiem samotność, przyjmująca w mistycyzmie formę wycofania się ze świata, byłaby czymś w rodzaju "twierdzy odosobnienia" (Burg der Absonderung), w której człowiek prowadzi dialog sam z sobą, wówczas

\footnotetext{
${ }^{19}$ Dostrzegalne jest np. podobieństwo do koncepcji mistycznej proponowanej przez Mistrza Eckharta.
} 
należałoby ją odrzucić jako prowadzącą do „upadku ducha w duchowość” (Abfall des Geistes zur Geistigkeit). Kuriozalną jest dla Bubera sytuacja, gdy duch odrywałby się od życia i od tego, co zewnętrzne: „Nie ma innego ducha niż duch karmiący się jednością życia i jednością ze światem” (Buber 1993: 83). Jeśli jednak samotność ma służyć oczyszczeniu i przygotować do obcowania ze świętością, a przecież również taki postulat znajdziemy w wielu koncepcjach mistycznych, to - jak autor przyznaje - „do tego jesteśmy stworzeni” (Buber 1992: 104-105).

Ponieważ kauzalizm należy do świata-To, nie jest możliwe, by mógł on w sposób trwały określać ludzką egzystencję, gdyż oznaczałoby to odmówienie człowiekowi wolności, tak ważnej dlań, wyróżniającej go na tle animalnego uniwersum. Człowiek jest przecież kimś niezdeterminowanym żadną koniecznością, kimś, kto wybiera, i właśnie w tym wyraża się duchowość, w której ma on swój udział (tamże: 72).

Podmiotowa i osobowa, a zarazem wychodząca ku człowiekowi realność tego, co duchowe jest dostępna w codziennym doświadczeniu, choć zarazem nie jest sprowadzalna do immanencji. Nie idzie tu zatem „o spotkanie z Platońskimi ideami (o których nic bezpośrednio nie wiem i których nie jestem w stanie pojąć, jako bytu), lecz z duchem, który nas owiewa i który nas wtajemnicza" (tamże: 120).

\section{Konkluzja}

Zasada, wedle której Buber rozróżnia dwie perspektywy duchowości - odrębne, niesprowadzalne do siebie - jest konsekwencją podstawowego założenia, patronującego dialogicznemu projektowi filozofa. Głosi ono, że istnieją dwa sposoby ludzkiego odnoszenia się do rzeczywistości - dialogiczne i monologiczne. Pierwsze bazuje na perspektywie egzystencjalno-relacyjnej, drugie na perspektywie poznawczo-uprzedmiotawiającej. Pierwsze, będące zarazem pierwszym genetycznie (i to zarazem w wymiarze onto- i filogenetycznym), pozwala na przejście do drugiego - odwrotna transformacja nie byłaby możliwa. A zatem dla Bubera nieskończoność jest tym, co bezprecedensowe, absolutnie „pierwsze” i właśnie z niej wyprowadza on skończoność. W tej kwestii koncepcja Bubera jest podobna do późniejszej propozycji Lévinasa, który - wbrew semantyczno-językowym intuicjom - podąża śladem Kartezjusza, zarazem różniąc się od Kanta, dla którego nieskończoność była „projekcją rozumu” (Lévinas 1998: 230-231). Podobną drogą podąża Buber, choć u niego punktem wyjścia jest nie tyle etyczne wezwanie, ile interpersonalna relacja. To właśnie tu, w transcendentnie ufundowanych i uwiarygodnionych realiach interpersonalnej relacji dostrzega to, co wcześniejsze od wszelkich immanentnie skonstruowanych realiów monologicznej przedmiotowości, która ufundowana jest na epistemicznym stosunku podmiotowo-przedmiotowym. I stosownie do tych opozycji, również życie $w$ duchu, jako otwierające się na transcendencję oraz na dar przyjmowany w ramach relacji międzyosobowej, niczym niezdetermi- 
nowanej, podejmowanej w sposób wolny, wymaga odróżnienia od życia duchowego, które jest - zgodnie z tym, jak Buber odczytuje jego sens - jedynie sublimacją wyższych stanów mentalnych podmiotu dającego się psychologicznie diagnozować w planie przyrodniczo-kulturowej skończoności. Zapewne niepodobna wykazać prawdziwość stanowiska zajmowanego przez Bubera, podobnie jak przesądzać o jego fałszywości - to stanowisko jest bowiem funkcją powziętych przezeń metafizycznych założeń. Jednak wedle Bubera odrzucenie takiej perspektywy stawia pod znakiem zapytania fortunność rozprawiania o „duchu” czy „duchowości”, gdyż określenia te sugerują odniesienie do jakiejś sfery, która przewyższa oraz poprzedza rzeczywistość ludzkiej immanencji, niezależnie od tego, na jakiej płaszczyźnie filozoficznego dyskursu byłby rozważany status ludzkiej podmiotowości, choć niewątpliwie różnica między porównywanymi w tekście określeniami staje się najbardziej transparentna $\mathrm{w}$ perspektywie egzystencjalnej i etycznej. Z jednej bowiem strony wyjątkowość ludzkiej egzystencji nie jest, wedle Bubera, osiągnięciem monologicznie funkcjonującego ludzkiego podmiotu, lecz funkcją dialogicznego daru, którego ostatecznym (pierwszym) źródłem jest transcendentne Ty, owo Ty, do którego prowadzą i w którym przecinają się linie wszystkich dialogicznych relacji (por. Buber 1973: 37; Buber 1992: 59). Z drugiej strony, skoro dialogiczna geneza człowieka, zakorzeniona jest w duchu jako absolutnej, pierwotnej i niezależnej od człowieka realności, to respektowanie tego stanu rzeczy stanowi doniosłą w kontekście „bycia ludzkim” 20 powinność. Innymi słowy, dla Bubera „żyć w duchu” to coś więcej niż istnieć jako człowiek. Racją życia w duchu - podobnie jak racją moralności - nie jest dobro ludzkiego Ja, lecz troska o Ty, które objawia ludzkiemu Ja prawdę o nieredukowalności i niezbywalności przysługującego mu osobowego statusu. Dlatego też życie w duchu nie jest powszednim biologiczno-kulturowym bytowaniem. Właściwszym jego określeniem byłoby raczej - by przywołać metaforę Lévinasa włączoną w tytuł jego słynnej książki - „inaczej niż być...” (Autrement qu'être...) (por. Lévinas 2000: 12, 230-231). Owo „inaczej” wskazuje na konieczność uwzględnienia w dyskursie o człowieku perspektywy, w której płaszczyzna poznawania, tworzenia i cywilizacyjnego gospodarowania okazuje się wtórna i podrzędna względem płaszczyzny dialogicznego bycia wobec Drugiego.

\section{Bibliografia}

Anzenbacher A. (1992) Wprowadzenie do filozofii, tłum. J. Zychowicz, Kraków, Wydawnictwo UNUM.

Barbour I. G. (1984) Mity. Modele. Paradygmaty, tłum. M. Krośniak, Kraków, Wydawnictwo Znak.

\footnotetext{
${ }^{20}$ Określenie „bycie ludzkim” (being human) pojawia się u Heschela i jest odróżnione od określenia „byt ludzki" (human being), jako że pierwsze, inaczej niż ostatnie, zakłada podejmowanie świadomych wyborów moralnych (por. Heschel 2014: 34-39).
} 
Böckenhoff J. (1970) Die Begegnungsphilosophie. Ihre Geschichte - ihre Aspekte, Freiburg-München, Karl Alber Verlag.

Buber M. (1973) Ich und Du w: M. Buber, Das dialogische Prinzip, Heidelberg, Verlag Lambert Schneider.

Buber M. (1992) Ja i Ty. Wybór pism filozoficznych, tłum. J. Doktór, Warszawa, Instytut Wydawniczy PAX.

Buber M. (1993) Problem człowieka, tłum. R. Reszke, Warszawa, Wydawnictwo Aletheia-Spacja.

Buber M. (1994) Zaćmienie Boga, tłum. P. Lisicki, Warszawa, Wydawnictwo KR.

Glinkowski W. P. (2011) Człowiek - istota spoza kultury. Dialogika Martina Bubera jako podstawa antropologii filozoficznej, Łódź, Wydawnictwo Uniwersytetu Łódzkiego.

Heschel A. J. (2001) Prosiłem o cud. Antologia duchowej mądrości, tłum. A. Gomola, Poznań, Wydawnictwo W drodze.

Heschel A. J. (2008) Człowiek szukajacy Boga. Szkice o modlitwie i symbolach, tłum. V. Reder, Kraków, Wydawnictwo Znak.

Heschel A. J. (2014) Kim jest człowiek?, tłum. K. Wojtkowska, Łódź-Warszawa, Wydawnictwo Uniwersytetu Łódzkiego - Wydawnictwo Punctum.

Hick J. (2005) Piąty wymiar. Odkrywanie duchowego królestwa, tłum. J. Grzegorczyk, Poznań, Wydawnictwo Zysk i S-ka.

Horkheimer M. (2007) Krytyka instrumentalnego rozumu, tłum. H. Walentowicz, Warszawa, Wydawnictwo Naukowe Scholar.

Lévinas E. (1998) Całość i nieskończoność. Esej o zewnętrzności, tłum. M. Kowalska, Warszawa, Wydawnictwo Naukowe PWN.

Lévinas E. (2000) Inaczej niż być lub ponad istotą, tłum. P. Mrówczyński, Warszawa, Fundacja Aletheia.

Moser M. (1979) Gotteserfahrung bei Martin Buber, Heidelberg, Verlag Lambert Schneider.

Paepcke F. (1986) Im Übersetzen leben - Übersetzen und Textvergleich, Tübingen, Günter Narr Verlag.

Paepcke F. (1990) Wielojęzyczność w poezji w: Komunikacja - rozumienie - dialog, B. Andrzejewski (red.), tłum. E. Andrzejewska, Poznań, Wydawnictwo Naukowe UAM, s. $135-144$. 
Ricoeur P. (1985) Symbol daje do myślenia, tłum. S. Cichowicz w: P. Ricoeur, Egzystencja i hermeneutyka. Rozprawy o metodzie, tłum. E. Bieńkowska, H. Bortnowska, S. Cichowicz, J. M. Godzimirski, H. Igalson, J. Skoczylas, K. Tarnowski, Warszawa, Wydawnictwo Znak.

Rotenstreich N. (1963) Gründe und Grenzen von Martin Bubers dialogischem Denken w: Martin Buber, P. A. Schilpp (red.), Stuttgart, W. Kohlhammer Verlag, s. 87-118.

Scheler M. (1987) O idei człowieka w: M. Scheler, Pisma z antropologii filozoficznej i teorii wiedzy, tłum. S. Czerniak, A. Węgrzecki, Warszawa, PWN, s. 3-42.

Theunissen M. (1977) Der Andere. Studien zur Sozialontologie der Gegenwart, BerlinNew York, Walter de Gruyter.

Theunissen M. (1991) Transcendentalny projekt ontologii społecznej a filozofia dialogu, tłum. J. Doktór w: Filozofia dialogu, B. Baran (red.), Kraków, Wydawnictwo Znak, s. 256-279.

Wehr G. (2007) Martin Buber. Biografia, tłum. R. Reszke, Warszawa, Wydawnictwo KR.

Whitehead A. N. (1997), Religia w tworzeniu, tłum. A. Szostkiewicz, Kraków, Wydawnictwo Znak. 